\title{
Coming full circle: the history of loss and damage under the UNFCCC
}

\author{
Erin Roberts* \\ Department of Geography, \\ King's College London, Strand Campus, \\ Strand, London WC2R 2LS, UK \\ Email: erin.roberts@kcl.ac.uk \\ Email: roberts.erin@gmail.com \\ *Corresponding author

\section{Saleemul Huq} \\ International Centre for Climate Change and Development, \\ 98 Park Road, Baridhara, Dhaka 1212, Bangladesh \\ Email: saleemul.huq@iiied.org
}

\begin{abstract}
This paper chronicles the history of the rise of loss and damage in negotiations under the United Nations Framework on Climate Change and the role of the Intergovernmental Panel on Climate Change in bringing about this paradigm shift. Over the past two decades, the global climate change regime has shifted from a focus primarily on mitigation, to both mitigation and adaptation and finally to the current era in which loss and damage has emerged as a key fixture on the agenda with the establishment of the Warsaw international mechanism on loss and damage at the 19th Conference of the Parties in November 2013. This shift can be attributed to the realisation that mitigation and adaptation efforts have been insufficient to avoid the impacts of climate change.
\end{abstract}

Keywords: climate change; United Nations Framework Convention on Climate Change; UNFCCC; negotiations; mitigation; adaptation; loss and damage; climate science; Intergovernmental Panel on Climate Change; IPCC.

Reference to this paper should be made as follows: Roberts, E. and Huq, S. (2015) 'Coming full circle: the history of loss and damage under the UNFCCC', Int. J. Global Warming, Vol. 8, No. 2, pp.141-157.

Biographical notes: Erin Roberts is a $\mathrm{PhD}$ student in the Department of Geography at King's College London and a visiting researcher at the International Centre for Climate Change and Development. Her research interests include development, vulnerability, climate change adaptation and the limits to adaptation, transformation and approaches to address loss and damage in developing countries.

Saleemul Huq is a Senior Fellow at the International Institute for Environment and Development and the Director of the International Centre for Climate Change and Development. His research interests include climate change adaptation and addressing loss and damage in least developed countries. 


\section{Introduction}

Loss and damage has become an increasing feature in the international climate change negotiations prompted by both increasingly severe predictions of the future impacts of climate change and evidence that loss and damage is already being incurred in communities the world over. Mitigation and adaptation efforts can reduce avoidable losses and damages (Verheyen, 2012). However, in some cases losses and damages will be incurred despite mitigation and adaptation efforts and thus there will be some losses and damages that will not be avoided (Ibid). A wide range of tools will need to be employed to both ensure that losses and damages are avoided to the extent possible through mitigation and adaptation action and address those residual impacts of climate change that are not avoided (UNFCCC, 2012a).

On 23 November 2013, a significant milestone was reached in the effort to address loss and damage when at the 19th Conference of the Parties (COP) to the United Nations Framework Convention on Climate Change (UNFCCC, hereafter known as 'the Convention') the Warsaw international mechanism for loss and damage associated with climate change impacts was established (UNFCCC, 2014). With the decision at COP 19 loss and damage has now become a fixture on the UNFCCC agenda over 20 years after the birth of the Convention. The establishment of the Warsaw international mechanism marks recognition that there are impacts of climate change that will not be avoided by mitigation and adaptation. This paper will chronicle the history of the UNFCCC from a single-minded focus on mitigation to a dual focus on both mitigation and adaptation to the current era in which loss and damage has emerged alongside adaptation and mitigation, an evolution that was accompanied by increasingly severe predictions of climate change in the reports of the Intergovernmental Panel on Climate Change (IPCC) (Folland et al., 2001; Parry et al., 2007 and IPCC, 2013). The fact that losses and damages from climate change - once purely conceptual - are now a reality reinforces the importance of mitigation in preventing future losses and damages while highlighting the integral role of adaptation and a suite of other approaches address current impacts.

\section{History of the UNFCCC}

\subsection{The Convention}

The global climate change regime was born almost a century after the first scientific evidence of anthropogenic climate change began emerging in the late 19th century. In 1864 American physicist John Tyndall discovered the capacity of $\mathrm{CO}_{2}$ for warming the atmosphere (Sherwood, 2011). Over three decades later, in 1896, Swedish scientist Svante Arrhenius maintained that doubling the amount of $\mathrm{CO}_{2}$ in the atmosphere would lead to an increase in temperature of between $5^{\circ} \mathrm{C}$ and $6^{\circ} \mathrm{C}$ while a tripling of $\mathrm{CO}_{2}$ would lead to an increase in temperature of between $7^{\circ} \mathrm{C}$ and nearly $10^{\circ} \mathrm{C}$ (Arrhenius, 1896). That same year fellow Swede Arvid Högbom discovered that industrial processes were contributing as much $\mathrm{CO}_{2}$ to the atmosphere as were natural processes, which over the coming centuries could lead to significant warming (Weart, 2010). This early work was largely ignored until in the 1930s when the study of anthropogenic global warming was revived by English engineer Guy Stewart Callendar. Callendar concluded that observed 
warming in the atmosphere was the result of a $10 \%$ increase in the concentration of $\mathrm{CO}_{2}$ in the atmosphere over the preceding century and warned that the warming would continue as the use of fossil fuels increased (Ibid). By the 1970s a scientific consensus was forming based on mounting evidence of the way in which human activities had contributed to a changing climate (Weart, 2010).

In the 1980s, science and politics began to mingle in the inception of a global effort to address climate change. In June of 1988, the World Meteorological Organization (WMO) convened a world conference entitled 'Changing atmosphere: implications for global security' in Toronto, which was attended by scientists and policymakers from 46 countries (WMO, 1988). The conference proceedings concluded that the average global temperature had risen by $0.5^{\circ} \mathrm{C}$ and if greenhouse gas (GHG) emissions continued to accelerate global mean temperatures could rise by between $1.5^{\circ} \mathrm{C}$ and $4.5^{\circ} \mathrm{C}$ by the end of the 21 st century (Ibid). Participants discussed the implications of climate change for human societies including threats to food security, a reduction in the availability of fresh water and its potential for jeopardising sustainable development and poverty reduction efforts. The conference proceedings concluded that, "if rapid action is not taken now by the countries of the world these problems will become progressively more serious, more difficult to reverse and more costly to address" (Ibid, p.293). That same month James Hansen, then director of the NASA Goddard Institute for Space Studies, declared the following during his testimony to US Congress:

\begin{abstract}
"My principle conclusions are: (1) the earth is warmer in 1988 than at any time in the history of instrumental measurements, (2) the global warming is now large enough that we can ascribe with a high degree of confidence a cause and effect relationship to the greenhouse effect and (3) our computer climate simulations indicate that the greenhouse effect is already large enough to begin to effect the probability of extreme events such as summer heat waves ..." [Hansen, (1988), p.39]
\end{abstract}

Later that year the IPCC was established by the WMO and the United Nations Environment Programme (UNEP) with the goal of increasing scientific understanding of climate change and its potential impacts (IPCC, n.d.).

With scientific consensus forming climate change became increasingly important in global politics. In December of 1988 the UN General Assembly issued a statement stressing that "climate change is a common concern of mankind" and urged government, intergovernmental and non-governmental actors to work together to develop a framework convention on climate change (UN General Assembly, 1988). In 1990, the IPCC released its First Assessment Report in which scientists expressed a belief that the global temperature rise over the past century had been between $0.3^{\circ} \mathrm{C}$ and $0.6^{\circ} \mathrm{C}$ (Folland et al., 1990). That same year UNEP and the WMO convened an ad hoc group of government representatives to discuss how international negotiations would be conducted to establish an international convention on climate change (Friman, 2007). Some developing countries argued that negotiations should take place under the auspices of the $\mathrm{UN}$, while many developed countries indicated a preference for the negotiations to be guided by the IPCC, UNEP or the WMO (Bodansky, 1994). In the end, the UN General Assembly established the Intergovernmental Negotiating Committee (INC) and charged it with developing a framework convention on climate change (UN General Assembly, 1990). The INC met five times before establishing the UNFCCC in June of 1992 at the UN Conference on Environment and Development in Rio de Janeiro. The final text of the Convention represents a compromise between Parties that wanted stringent targets and 
Parties that wanted a skeletal framework according to Sands (1992). The Convention was widely endorsed, perhaps because it represented a compromise that everyone could agree to. Bodansky (1995, p.426) refers to the emerging climate change regime as a 'hedging strategy' which though finally recognising climate change as a serious long-term issue did not require the implementation of significant mitigation and adaptation measures to address the issue. Originally signed by 155 states as well as the European Community (Sands, 1992), the Convention has since been signed and ratified by 195 Parties (UNFCCC, n.d.).

\subsection{Mitigation}

The ultimate objective of the Convention - laid out in Article 2 - is "the stabilization of GHG concentrations in the atmosphere at a level thatwould prevent dangerous anthropogenic interference with the climate system" [UN, (1992), p.4]. In an effort to avoid anthropogenic climate change to the extent possible negotiations under the Convention focused on mitigation for the first decade and a half of its existence (Warner and Zakieldeen, 2012). After the Convention was ratified in 1992 the INC continued to meet, a total of six times, before the first COP, held in Berlin in March of 1995. According to Ramakrishna (2000) in these meetings, developed countries began arguing that developing country Parties should join in the next phase of mitigation commitments. At this first COP the Ad-hoc Working Group on the Berlin Mandate was given the task of developing a set of rules and guidelines to guide the development of a protocol to set out binding emission reduction targets, with the aim of adopting the instrument at COP 3 in late 1997 [Grubb (1999) in Friman (2007)]. These efforts were driven by significant political will. In late June of 1997 a special session of the UN General Assembly was held during which many of the world's leaders emphasised the need to adopt a protocol at COP 3 in Kyoto later that year (Ramakrishna, 2000).

The Kyoto Protocol was developed in an atmosphere in which most climate scientists agreed that the Earth was warming as a result of anthropogenic GHG emissions and that further warming could be expected (Schneider, 1998). In 1996, the IPCC's Second Assessment Report was released, which predicted that depending on emission scenarios between 1990 and 2100 global mean temperature would likely increase by between $0.9^{\circ} \mathrm{C}$ and $3.5^{\circ} \mathrm{C}$ (Schimel et al., 1996). Schneider (1998) credits this atmosphere for convincing governments of the necessity of taking action even in light of uncertainty about future climate change. However, the uncertainty also meant that policymakers were unsure of both the extent to which emissions should be reduced and the timeline for doing so ('Politicians sweat over global warming', 1997). The USA arrived in Kyoto with the position that tackling the problem of global warming should involve the participation of all countries, while the least developed countries (LDCs) asserted that the principle of equity meant that they should be exempt from emission cuts until their economies approached the development level of middle-income developing countries (Schneider, 1998). Najam and Sajar (1998) suggest the negotiations sidelined the "much-needed debate on specific and detailed criteria to apportion responsibilities among nations to achieve the goals of the UNFCCC".

The Kyoto protocol was adopted in December of 1997 after 11 days of intense negotiations (Ibid). Politics reigned over pragmatism and the emission cuts laid out in the Kyoto Protocol were modest. The Kyoto Protocol outlined targets for Annex I Parties 38 industrialised countries - for the commitment period 2008 to 2012 (UNFCCC, 1998). 
If achieved, these targets would have reduced emissions for this group of countries by $5.2 \%$ from 1990 levels (Ramakrishna, 2000). The USA - which at the time contributed $25 \%$ to global emissions - agreed to a 7\% cut, the EU $8 \%$ and Japan 5\% (Schneider, 1998). Many climate scientists warned that the targets were not sufficient to slow, much less halt, climate change and that much more ambitious cuts would be needed in the future to significantly reduce the rate at which the climate was changing (Malakoff, 1997). In an interview conducted a year after the Kyoto Protocol was created, American climate scientist Jerry Mahlman famously stated that it would take 30 Kyoto Protocols to reduce global warming (Ibid). That said, while many criticised the Kyoto Protocol, others saw it as the first step in a long process to address climate change (Ibid).

Ultimately, the USA - though a signatory to the Kyoto Protocol- was never able to ratify it due to the passing of the Byrd-Hagel Resolution by the U.S. Senate, which prevented the USA from signing a protocol that committed developed country Parties to emission cuts without commitments on the part of developing country Parties (Ramakrishna, 2000). The failure of the world's largest emitter to ratify the Kyoto Protocol further reduced already low confidence in the ability of the global climate regime to successfully stabilise GHG emissions and slow - if not stop entirely - the progression of global climate change.

The focus on mitigation during the first decade of the UNFCCC can at least partly be attributed to a belief - or perhaps more aptly, naïveté - that mitigation efforts would be enough to stabilise GHG levels in the atmosphere. Pielke (1998) asserts that this faith was also likely based on the precedent set by the Montreal Protocol and the successful reduction of ozone in the atmosphere. However, the science behind ozone depletion was not as complex as that of climate change and the number of actors involved in taking action to reduce ozone in the atmosphere was not as great (Ibid). In addition there remained uncertainty about the way in which human activities were contributing to climate change (Klein et al., 2003). However, scientific evidence of anthropogenic climate change and its associated impacts was continuing to evolve. The IPCC's Second Assessment Report maintained that even if GHG levels were stabilised before 2100 global mean temperature would continue to rise beyond that (Schimel et al., 1996). The report also warned that:

\begin{abstract}
"Decisions taken during the next few years may limit the range of possible policy options in the future, because high near-term emissions would require deeper reductions in the future to meet any given target concentrations. Delaying action might reduce the overall costs of mitigation because of potential technological advances but could increase both the rate and eventual magnitude of climate change, hence the adaptation and damage costs." [IPCC Working Group I, (1996), p.4]
\end{abstract}

Between the IPCC's second and third assessment reports confidence in the ability of climate models to project future climate increased (Houghton et al., 2001). In 2001, the IPCC's Third Assessment Report was released, which with the help of more sophisticated modeling predicted warming between $1.4^{\circ} \mathrm{C}$ by $5.8^{\circ} \mathrm{C}$ by 2100 for a range of emission scenarios (Ibid). With the release of the IPCC's Fourth Assessment Report in 2007 it was clear that mitigation efforts had thus far been insufficient to avoid prevent climate change impacts (Warner and Zakieldeen, 2012). It was becoming increasingly evident that more ambitious mitigation efforts would be required to limit the impacts of climate change and prevent losses and damages. That said, even if mitigation had been pursued ambitiously from the very inception of the UNFCCC there would still have been a certain amount of 
climate change impacts that would be unavoidable given historical emissions (Pielke, 1998; Pielke et al., 2007; Klein et al., 2003). Therefore by the mid-2000s discussions that focused on how to help developing countries adapt to the impacts of climate change became a more prominent part of the international climate change negotiation process (Warner and Zakieldeen, 2012).

\subsection{Adaptation}

Though the ultimate objective of the Convention is to stabilise GHG concentrations at levels that would prevent "dangerous anthropogenic interference with the climate system" the importance of adaptation was acknowledged by the document's architects. Article 4.1 calls on Parties to implement adaptation strategies, accounting for both their common but differentiated responsibilities and varying development priorities, objectives and circumstances (UN, 1992). Article 4.4 maintains that developed country Parties should provide support to help particularly vulnerable developing country Parties meet the costs of adapting to climate change (Ibid). In addition Article 4.8 states that "Parties shall give full consideration to what actions are necessary under the Convention, including actions related to funding, insurance and the transfer of technology, to meet the specific needs and concerns of developing country Parties arising from the adverse effects of climate change" (Ibid, pp.8-9). The necessity of adaptation - and specifically of the need to support developing country's adaptation efforts - was thus recognised from the very beginning of the global climate change regime.

However, though the Convention mentions both mitigation and adaptation, there has long been tension between the two priorities. In fact even while the Convention was being drafted, Tarlock (1992) argued that global debate on climate change was being framed as a choice between either mitigation or adaptation despite the fact that the costs of adaptation were likely much higher than those of reducing emissions. More than a decade after the Convention was established Schipper (2006, p.82) argued that, "tension between those in favour of mitigation over adaptation activities has strongly characterised the discourse on climate change policy." The fact that adaptation does not factor as heavily into the Convention as does mitigation is an indication both in the belief that impacts climate change would be successfully avoided through mitigation efforts as well as uncertainty about the manner in which climate change would manifest and what would be required to successfully adapt to those changes (Ibid). Burton (1994) proposes that Parties and other actors including scientists and climate activists were also reluctant to bring the issue of adaptation into early negotiations for fear of being seen as fatalists or lacking commitment to mitigate. In addition there was a prevailing perception that there needed to be more certainty about the future of climate impacts in order to plan adaptation activities (Pielke, 1998).

The fluidity of the concept of adaptation and the fact that it can mean different things to different people also likely played a role in sidelining discussions on adaptation under the UNFCC. The very nature of adaptation makes it difficult to define. Nordhaus (1994, p.189) famously argued, "mitigate we might; adapt we must." Adaptation is a fact of life, something that is done every day to adapt to changes in one's environment (Burton et al., 1993). In its Third Assessment Report, the IPCC defined adaptation as, "adjustment in ecological, social or economic systems in response to actual or expected climate stimuli" [Smit et al., (2001), p.879]. However, this definition is broad and fails to incorporate the context in which adaptation takes place. Smithers and Smit (1997) highlight the 
complexity of adaptation and emphasise the fact that it does not occur in isolation but in varying social, political and institutional contexts. In addition, while mitigation actions are largely taken at the national level by governments, adaptation measures are generally implemented at the local level by local actors (Tol, 2005). Unsurprisingly given the diverse views on what constitutes adaptation, there is no agreed upon definition of adaptation in the UNFCCC. However, there have been attempts to develop a universal definition of adaptation. During the INC negotiations that preceded the establishment of the Convention Australia and New Zealand proposed that adaptation is an "all purposeful and deliberate activity taken in response to or anticipation of the adverse effects of rapid climate change" [Schipper, (2006), p.88]. The two countries proposed a process whereby an agreed upon definition for adaptation could be developed but this proposal was never pursued (Ibid).

Another reason why adaptation emerged slowly and lacked direction in the global climate regime is because unlike mitigation, it was not as explicitly laid out in the Convention as adaptation (Schipper, 2006). The UNFCCC was developed in order to respond to anthropogenic emissions; and therefore the implication is that adaptation activities under the UNFCCC should be focused on responding to human-induced climate change impacts (Pielke et al., 2007). However, many view adaptation in the broader context of sustainable development such that adaptation strategies not only promote adaptation to anthropogenic climate change but to other changes in society as well (Ibid; Schipper, 2006; Kates, 2000). Most importantly however, it was recognised that adaptation was not a long-term solution for climate change and eventually GHG emissions would have to be stabilised at a 'tolerable' level (Burton et al., 2002). Despite this, there were some early discussions on adaptation needs under the Convention in the early days of the global climate change regime.

Alongside negotiations to develop a protocol for emissions reductions Parties discussed adaptation priorities at the first COP in Berlin in 1995. Paragraph 1d of Decision 11/CP.1 outlined policies, program priorities and eligibility criteria for adaptation strategies including studies to understand the possible impacts of climate change, identify particularly vulnerable countries or regions and determine policy options for adaptation and appropriate capacity-building in the short-term, measures to build capacity in the medium-term and activities to facilitate adaptation including insurance and other measures in the long-term (UNFCCC, 1995).

Focus began to shift more intently to adaptation shortly before the Convention celebrated its tenth anniversary. When the USA failed to ratify the Kyoto Protocol in March of 2001 it became clear that mitigation efforts would not proceed as had been hoped. According to Burton et al. (2002) developing country Parties were instrumental in highlighting the adaptation needs of vulnerable countries and ensuring that steps were taken to address these needs within the UNFCCC. At COP 7 in Marrakesh in late 2001 three funds were established to provide finance for adaptation - among other -activities in developing countries - including the Least Developed Country Fund, the Special Climate Change Fund and the Adaptation Fund. Decision 5/CP.7 determined that the Global Environment Facility would support activities to address vulnerability and adaptation, including enabling activities for vulnerability and adaptation assessment, enhancing capacity to integrate adaptation into sustainable development program and promoting transfer of adaptation technologies, among others (UNFCCC, 2002). The Marrakesh Accords also established a work program to support the activities of LDCs, including the development and implementation of National Adaptation Programmes of 
Action (NAPAs) to determine urgent adaptation priorities. Again processes under the UNFCCC closely mirrored emerging themes in academia and the science of climate change. The IPCC's Working Group II's contributions to the Second Assessment Report was entitled 'Impacts, Adaptation and Mitigation of Climate Change', which became 'Impacts, Adaptation and Vulnerability' for the third and fourth assessment reports.

Despite the fact that adaptation was slowly gaining ground, many felt that it was still under-emphasised in the UNFCCC process and some even called for a separate protocol on adaptation (Burton, 2005). In the Delhi Declaration at COP 8 in 2002 several Parties demanded more attention to adaptation in a statement that maintained that:

\begin{abstract}
"Adaptation to the adverse effects of climate change is of high priority for all countries. Developing countries are particularly vulnerable, particularly least developed countries and small island developing states. Adaptation requires urgent attention and action on the part of all countries. Effective and resultbased measures should be supported for the development of approaches at all levels on vulnerability and adaptation, as well as capacity-building for the integration of adaptation concerns into sustainable development strategies." [UNFCCC, (2003), p.4]
\end{abstract}

It is unclear what role the Delhi Declaration played, but in the years immediately following COP 8 , focus on adaptation, and providing resources to implement adaptation activities, increased. The contributions of the IPCC also played a role in the evolution of adaptation under the UNFCCC (Warner and Zakieldeen, 2012; Burton et al., 2002). After the IPCC's Third Assessment Report was released, which contained increasingly severe climate change predictions than the previous two assessment reports, focus on adaptation increased (Burton et al., 2002). Subsequently at COP 9 in 2003 Parties requested the UNFCCC to facilitate a process to enhance understanding and facilitate an exchange of knowledge on the "scientific, technical and socio-economic aspects of impacts of, and vulnerability and adaptation to, climate change, and scientific, technical and socio-economic aspects of mitigation ..." [UNFCCC, (2004), p.19]. Two years later at COP 11, a five-year work program was established under the Subsidiary Body for Scientific and Technological Advice to enhance understanding of impacts, vulnerability and adaptation to climate change (UNFCCC, 2006). At COP 12 the work program was renamed the Nairobi work program on impacts, vulnerability and adaptation to climate change and the activities that were identified in previous decisions were thereafter initiated (UNFCCC, 2007).

By 2005 adaptation had become a 'central challenge' within the UNFCCC process (Mace, 2005). The Bali Action Plan, developed at COP 13 in Bali in 2007 contains several strongly worded provisions on enhancing adaptation, including the need for "international cooperation to support [the] urgent implementation of adaptation actions" [UNFCCC, (2008), p.4]. The decision also highlighted the importance of risk management and risk reduction strategies as well as those aimed at building resilience (Ibid). It is clear from both the provisions and the wording used to emphasise their necessity that adaptation was becoming increasingly important as climate change impacts were becoming increasingly evident. However, adaptation was still scattered throughout the UNFCCC agenda.

The Cancun Adaptation Framework (CAF) established at COP 16 in Cancun, helped address some of the adaptation needs more holistically under the Convention. Decision 1/CP.16 established a process to support LDCs in the development and implementation of national adaptation plans (NAPs) to identify medium and long-term adaptation 
priorities (UNFCCC, 2011a). The decision also invited other developing countries to use the same process to develop their own NAPs (Ibid). The CAF also established the Adaptation Committee to "promote the implementation of enhanced action on adaptation in a coherent manner" [UNFCCC, (2011a), p.5]. In its first meeting in September 2012 members of the Adaptation Committee developed a three-year work plan containing a long list of activities, several of which emphasise the need to promote coherence among bodies, both in and outside of the UNFCCC process, address gaps and avoid replication (UNFCCC, 2012b).

Though mitigation continues to be the priority of the UNFCCC adaptation is an increasing focus of negotiations. As Klein et al. (2003) note, while adaptation is a necessity pursuing adaptation without mitigation could lead to the need for levels of adaptation that carry significant economic and social burdens. Thus, both mitigation and adaptation are essential in the global effort to address climate change. However, in recent years it has become increasingly apparent that even a combination of mitigation and adaptation cannot prevent the impacts of climate change from manifesting, especially in vulnerable countries. This realisation has brought loss and damage to the fore, not for the first time, but this time the reality that climate change impacts are already inflicting losses and damages, combined with predictions of future climate change, has prompted loss and damage to become a fixture on the UNFCCC agenda.

\section{Loss and damage}

Concern over the potential losses and damages from climate change impacts predates the formation of the Convention. In 1991, Vanuatu submitted a proposal to the INC on behalf of the Alliance of Small Island States (AOSIS) in which it proposed the establishment of both an international fund to support measures to address the impacts of climate change as well as an insurance pool to provide insurance against sea level rise (INC, 1991). The proposal suggested that the revenue for the insurance pool should come from mandatory contributions from developed countries, and that the resources should be used to "compensate small island states along with low lying developing countries for loss and damage resulting from the consequences of sea level rise" (Ibid:2). The aim of the proposal was to establish a compensation fund that would redress direct damage from the adverse effects of sea level rise (Linnerooth-Bayer et al., 2003).

In the end neither the concept of an insurance pool nor a compensatory fund were incorporated into the Convention. Instead Article 4.8 states:

\footnotetext{
"Parties shall give full consideration to what actions are necessary under the Convention, including actions related to funding, insurance and the transfer of technology, to meet the specific needs and concerns of developing country Parties arising from the adverse effects of climate change and/or the impacts of the implementation of response measures ..." [UN, (1992), pp.8-9]
}

Very little was heard about insurance during the early negotiations that focused on developing the Kyoto Protocol. Not until COP 7 in Marrakesh did the issue of insurance arise again, when Decision 5/CP.7 decided to "consider, at its eighth session, the implementation of insurance-related actions to meet the specific needs and concerns of developing country Parties arising from the adverse effects of climate change" 
[UNFCCC, (2002), p.36]. However, in the end there was no decision on insurance at COP 8 in Delhi.

While - as shown above - the concept of losses and damages from climate change impacts predates the Convention itself, the phrase "loss and damage" emerged for the first time in a UNFCCC text in the Bali Action Plan, which arose from COP 13. Article 1c of Decision 1/C.P 13 calls for enhanced action on adaptation including:

"Disaster risk reduction strategies and means to address loss and damage associated with climate change impacts in developing countries that are particularly adverse to the impacts of climate change." [UNFCCC, (2008), p.4]

A subsidiary body - the Ad Hoc Working Group on Long-term Cooperative Action under the Convention (AWG-LCA) - was created to implement the Bali Action Plan (Ibid). In response to a call for submissions on how the work of the AWG-LCA should be carried out AOSIS submitted a proposal for a multi-window mechanism to address loss and damage from the adverse impacts of climate change. The proposed mechanism consisted of three inter-dependent components, including:

1 an insurance component to address climate-related extreme weather events and risks to crop production, food security and livelihoods

2 a rehabilitation and compensatory component to address progressive negative impacts that result in loss and damage

3 a risk management component to promote risk assessment and risk management tools and strategies at all levels [AOSIS, (2008), p.1].

The fact that loss and damage appeared for the first time in a UNFCCC document shortly after the IPCC's Fourth Assessment Report was launched is not a coincidence. The release of the report made it clear that mitigation efforts were insufficient to avoid impacts of climate change (Warner and Zakieldeen, 2012). Working Group II's contribution to Fourth Assessment Report drew attention to "critical thresholds beyond which some systems may not be able to adapt to changing climate conditions without radically altering their functional state and system integrity" (Parry et al., 2007). While the report helped increase the focus on and importance of adaptation in the global climate regime, it also highlighted the limits of adaptation. Thus the Convention began referring to a broader range of risk management tools with which to address climate change.

The momentum on loss and damage gathered in Bali continued through Cancun, culminating in a decision at COP 16 in 2010, which established a work program damage to consider approaches to address loss and damage in developing countries particularly vulnerable to the impacts of climate change (UNFCCC, 2011a). The following spring at the 34th session of the Subsidiary Body for Implementation (SBI), the work program was further differentiated into three thematic areas:

1 assessing the risk of loss and damage associated with the adverse effects of climate change and the current knowledge on the same

2 a range of approaches to address loss and damage associated with the adverse effects of climate change, including impacts related to extreme weather events and slow onset events, taking into consideration experience at all levels 
3 the role of the Convention in enhancing the implementation of approaches to address loss and damage associated with the adverse effects of climate change [UNFCCC, (2011b), p.17-18].

In November of 2011, shortly before the seventeenth COP, the IPCC released the Summary for Policymakers from the Special Report on Managing the Risks of Extreme Events and Disasters to Advance Climate Change Adaptation (SREX). The report's authors maintained that future climate change would be accompanied by increasing magnitude and in some cases frequency of extreme events (IPCC, 2012). To effectively manage the risk of extreme events SREX recommended a 'portfolio of actions' including risk reduction, risk transfer and disaster response (Ibid).

The complexity of loss and damage became evident during negotiations at COP 17 in Durban. The SBI was asked to continue the work program and to make recommendations on loss and damage the following year at COP 18 (UNFCCC, 2012c). Throughout 2012 a series of expert meetings were held to discuss the needs associated with assessing and addressing loss and damage in developing countries at the national, regional and international levels. Discussions at these meetings helped move the loss and damage debate forward such that a decision at COP 18 in Doha in late 2012 was possible.

Negotiations on loss and damage at COP 18 in Doha focused on the third thematic area of the work program: the role of the Convention. In Doha, Parties agreed that 'comprehensive, inclusive and strategic' approaches are needed to address loss and damage and decided that the role of the Convention is:

1 enhancing knowledge and understanding of comprehensive risk management approaches to address loss and damage associated with the adverse effects of climate change, including slow onset impacts

2 strengthening dialogue, coordination, coherence and synergies among relevant stakeholders

3 enhancing action and support, including finance, technology and capacity-building, to address loss and damage associated with the adverse effects of climate change (UNFCCC, 2013).

In order to help the Convention achieve its mandated roles vis-à-vis loss and damage in Parties it was decided that institutional arrangements - including an international mechanism - would be established at COP 19 in Warsaw (Ibid). A range of actions to help countries address loss and damage were also highlighted along with the need to continue to improve understanding of loss and damage including non-economic losses and how loss and damage affects vulnerable segments of populations and influences patterns of migration and mobility - among other key issues on the research agenda (Ibid).

While there were no formal negotiations on loss and damage between COP 18 and COP 19 there was work to advance the research, particularly on improving understanding of the limits to adaptation. Dow et al. (2013, p.306) defined the limits of adaptation as the point at which "an actor can no longer secure valued objectives from intolerable risk through adaptive action". Preston et al. (2013) introduced the concept of the adaptation frontier or a theoretical "safe operating space for adaptation" within which the risk of 
climate change impacts can be kept at a tolerable level if the appropriate adaptation strategies are adopted. The concept of the limits to adaptation was thrust into the spotlight during the last minute negotiations on the wording of the final decision on loss and damage at COP 19 in Warsaw.

Two events occurred just prior to the nineteenth COP, which highlighted the urgency of addressing loss and damage. First, in September of 2013 the IPCC released the Summary for Policymakers of Working Group I's contributions to the IPCC's Fifth Assessment Report. The document warned that limiting warming to $2^{\circ} \mathrm{C}$ compared to the period between 1861 and 1880 with a probability of more than $33 \%, 50 \%$ and $66 \%$ respectively would require that cumulative emissions stay below 900,820 and 790 gigatonnes (GtC) of $\mathrm{CO}_{2}$ respectively (IPCC, 2013). With $515 \mathrm{GtC}$ having already been emitted up to 2011 this meant that the window for keeping warming below $2{ }^{\circ} \mathrm{C}$ was quickly closing (Ibid). Second, Typhoon Haiyan - the most powerful storm to make landfall in recorded history (Fischetti, 2013) hit Southeast Asia, leaving over 6,000 dead and over 27,000 injured in the Philippines alone (Bradsher, 2013). Days after Typhoon struck his homeland Naderev (Yeb) Sano, the head Philippine delegation, made an impassioned plea for swift action to address climate change at the opening plenary of COP 19 in Warsaw (Vidal and Vaughan, 2013).

After over two weeks of negotiations at COP 19, Parties finally agreed on a decision in an eleventh hour huddle on the plenary floor. The decision acknowledges that "loss and damage associated with the adverse effects of climate change includes, and in some cases involves more than, that which can be reduced by adaptation" (UNFCCC, 2014). The Warsaw international mechanism for loss and damage associated with climate change impacts was established under the CAF with a review of the structure, mandate and effectiveness to take place at COP 22 (Ibid). The Warsaw international mechanism is mandated to fulfil the role of the Convention as determined by Parties at COP 18, which included enhancing knowledge and understanding of how risk management tools can be used to address loss and damage; strengthening dialogue, coordination and coherence and synergies amongst relevant stakeholders and enhancing action and support to address loss and damage (Ibid). The establishment of the Warsaw international mechanism marks the beginning of a process under the Convention to address residual losses and damages not avoided by mitigation and adaptation.

\section{Conclusions}

In the last two decades, the UNFCCC process has undergone a metamorphosis. Underlying this shift is low levels of mitigation ambition and the subsequent erosion of the belief that mitigation efforts at their current levels can successfully stabilise GHGs enough to prevent climate change impacts. For the first decade and a half of its existence the global climate regime focused on preventing dangerous climate change through mitigation efforts. Many were reluctant to focus on adaptation in the early days of the global climate change process for fear that it would shift focus from mitigation. However, in the 2000s, with the release of the third and subsequently fourth assessment reports of the IPCC the predictions of future climate change impacts became increasingly dire. While efforts to prevent catastrophic levels of climate change in the longer term remained the key objective of discussions under the UNFCCC, adaptation received increasing 
attention in the negotiation process. In the late 2000s, it became evident to developing country Parties that even substantial progress in adaptation could not prevent the adverse consequences of climate change in some communities. Clearly addressing climate change and its impacts would require a more comprehensive set of tools.

Loss and damage made its first appearance in a UNFCCC document in the Bali Action Plan, the result of negotiations at COP 13 in 2007. In 2010 loss and damage was given its own work program as part of the CAF. Three years later institutional arrangements were created to help developing countries implement a spectrum of actions to address loss and damage. With the establishment of the Warsaw international mechanism on loss and damage the UNFCCC is now entering a new phase marked by recognition that neither mitigation nor adaptation - at their current levels - will be enough to prevent losses and damages from climate change impacts, which are in fact already happening now.

As the above narrative has shown the concept of residual loss and damage is not a new entry into discussions under the UNFCCC, having first been proposed by AOSIS in 1991. However, after two decades of negotiations and emission levels that have increased rather than decreased the point has been reached at which serious long-term consequences of climate change are more of a foregone conclusion than a possibility. Research has found that despite implementing strategies to cope and adapt some communities in developing countries are already incurring losses and damages (Warner and van der Geest, 2013). Historical emissions have locked in a certain level of climate change (IPCC, 2013). Thus, even with high levels of mitigation and adaptation there will be some residual loss and damage (Klein et al., 2014). Policymakers in developing countries need to understand when to implement approaches to avoid loss and damage and when strategies to address unavoidable losses and damages are needed (Huq et al., 2013). Thus, loss and damage will likely become an even more important part of the global climate regime in the years to come.

Though the window is fast closing, limiting warming to below $2{ }^{\circ} \mathrm{C}$ remains a possibility. However, to achieve this goal will require swift and significant emission reductions. In reinforcing the importance of mitigation, the loss and damage agenda has brought the UNFCCC full circle. However, with the realisation that given predictions of what impacts climate change may bring in the future mitigation efforts must not only be scaled up but accompanied by efforts to further reduce loss and damage through adaptation and measures to address those residual losses and damages not avoided.

\section{Acknowledgements}

The authors would like to thank the two anonymous reviewers for their insightful comments. In addition, the authors would also like to thank partners in the Loss and Damage in Vulnerable Countries Initiative, including Koko Warner, Kees van der Geest, Sönke Kreft, Sven Harmeling, Lisa Meier and Michael Zissener as well as the Climate and Development Knowledge Network for its funding support. The corresponding author would also like to thank her PhD supervisor Mark Pelling for his guidance and support during the development of this paper. 


\section{References}

AOSIS (2008) Proposal to the AWG-LCA: Multi-Window Mechanism to Address Loss and Damage from Climate Change Impacts [online]

http://unfccc.int/files/kyoto_protocol/application/pdf/aosisinsurance061208.pdf (accessed 17 October 2013).

Arrhenius, S. (1896) 'On the influence of carbonic acid in the air upon the temperature of the ground', Philosophical Magazine and the Journal of Science, Vol. 41, No. 5, pp.237-276.

Bodansky, D. (1994) 'Prologue to the climate change convention', in Mintzer, I.M. and Leonard, J.A. (Eds.): Negotiating Climate Change - The Inside Story of the Rio Convention, Cambridge University Press, Cambridge.

Bodansky, D.M. (1995) 'The emerging climate change regime', Annual Review of Energy and the Environment, Vol. 20, pp.425-461.

Bradsher, K. (2013) Kerry Calls Typhoon a Warning of Climate Change, New York Times [online] http://www.nytimes.com/2013/12/19/world/asia/typhoon-haiyan-philippines-aid.html (accessed 23 January 2014).

Burton, I. (1994) 'Deconstructing adaptation ... . and reconstructing', Delta, Vol. 5, No. 1, pp.14-15.

Burton, I. (2005) 'Adapt and thrive: options for reducing the climate change adaptation deficit', Policy Options, December-January, pp.33-38 [online] http://policyoptions.irpp.org/wpcontent/uploads/sites/2/assets/po/global-warming-a-perfect-storm/burton.pdf (accessed 14 October 2013).

Burton, I., Huq, S., Lim, B., Pilifosova, O. and Schipper, E.L. (2002) 'From impacts assessment to adaptation priorities: the shaping of adaptation policy', Climate Policy, Vol. 2, pp.145-159.

Burton, I., Kates, R.W. and White, G.F. (1993) The Environment as Hazard, Guildford Press, London.

Dow, K., Berkhout, F., Preston, B.L., Klein, R.J.T, Midgley, G. and Shaw, M.R. (2013) 'Commentary: limits to adaptation', Nature Climate Change, Vol. 3, pp.305-307.

Fischetti, M (2013) Was Typhoon Haiyan a Record Storm, Scientific American [online] $\mathrm{http} / / / \mathrm{blogs}$.scientificamerican.com/observations/2013/11/12/was-typhoon-haiyan-a-recordstorm/ (accessed 23 January 2014).

Folland, C.K., Karl, T.R. and Vinnikov, K.Y.A. (Eds.) (1990) 'Observed climate variations and change', in Houghton, J.T., Jenkins, G.J. and Ephraums, J.J. (Eds.): Report Prepared for Intergovernmental Panel on Climate Change by Working Group I, Cambridge University Press, Cambridge, New York and Melbourne.

Folland, C.K., T.R. Karl, J.R. Christy, Clarke, R.A., Gruza, G.V., Jouzel, J., Mann, M.E., Oerlemans, J., Salinger, M.J. and Wang, S-W. (2001) '2001: Observed Climate Variability and Change', in Houghton, J.T., Ding, Y., Griggs, D.J., Noguer, M., van der Linden, P.J., Dai, X., Maskell, K. and Johnson, C.A. (Eds): Climate Change 2001: The Scientific Basis. Contribution of Working Group I to the Third Assessment Report of the Intergovernmental Panel on Climate Change, Cambridge University Press, Cambridge and New York.

Friman, M. (2007) Historical Responsibility in the UNFCCC, Centre for Climate Science and Policy Research, Linköping, Sweden.

Hansen, J. (1988) 'The greenhouse effect: impacts on current global temperature and regional heat waves', statement of James E. Hansen, presented to the United States Senate Committee on Energy and Natural Resources, 23 June 1988 [online] http://image.guardian.co.uk/sysfiles/Environment/documents/2008/06/23/ClimateChangeHearing1988.pdf (accessed 26 November 2013).

Huq, S., Roberts, E. and Fenton, A. (2013) 'Commentary: loss and damage', Nature Climate Change, Vol. 3, pp.947-949.

INC (1991) Vanuatu: Draft Annex Relating to Article 23 (Insurance) for Inclusion in the Revised Single Text on Elements Relating To Mechanisms, A/AC.237/WG.II/Misc.13. 
IPCC (2012) Managing the Risks of Extreme Events and Disasters to Advance Climate Change Adaptation. A Special Report of Working Groups I and II of the Intergovernmental Panel on Climate Change, Field, C.B., Barros, V., Stocker, T.F., Qin, D., Dokken, D.J., Ebi, K.L., Mastrandrea, M.D., Mach, K.J., Plattner, G-K., Allen, S.K., Tignor, M. and Midgley, P.M. (Eds.), Cambridge University Press, Cambridge and New York.

IPCC (2013) 'Summary for policymakers', in Stocker, T.F., Qin, D., Plattner, G-K., Tignor, M., Allen, S.K., Boschung, J., Nauels, A., Xia, Y., Bex, V. and Midgley, P.M. (Eds.): Climate Change 2013: The Physical Science Basis. Contribution of Working Group I to the Fifth Assessment Report of the Intergovernmental Panel on Climate Change, Cambridge University Press, Cambridge and New York.

IPCC (n.d.) History [online] http://www.ipcc.ch/organization/organization_history.shtml\#.UpYQz6UspuY (accessed 26 November 2013).

IPCC Working Group I (1996) 'Summary for policymakers', in Houghton, J.T., Meira Filho, L.G., Callander, B.A., Harris, N., Kattenberg, A. and Maskell, K. (Eds.): Climate Change 1995 The Science of Climate Change: Contribution of Working Group I to the Second Assessment Report of the Intergovernmental Panel on Climate Change, Cambridge University Press, Cambridge, New York and Melbourne.

Kates, R.W. (2000) 'Cautionary tales: adaptation and the global poor', Climatic Change, Vol. 45, No. 1, pp.5-17.

Klein, R.J.T., Schipper, E.L. and Dessai, S. (2003) Integrating Mitigation and Adaptation Into Climate and Development Policy: Three Research Questions, Tyndall Centre for Climate Change Research Working Paper 40 [online] http://www.tyndall.ac.uk/sites/default/files/wp40.pdf (accessed 11 February 2014).

Klein, R.J.T., Midgley, G.F., Preston, B.L., Alam, M., Berkhout, F.G.H., Dow, K. and Shaw, M.R. (2014) 'Adaptation opportunities, constraints and limits', in Field, C.B., Barros, V.R., Dokken, D.J., Mach, K.J., Mastrandrea, M.D., Bilir, T.E., Chatterjee, M., Ebi, K.L., Estrada, Y.O., Genova, R.C., Girma, B., Kissel, E.S., Levy, A.N., MacCracken, S., Mastrandrea, P.R. and White, L.L. (Eds.): Climate Change 2014: Impacts, Adaptation, and Vulnerability: Contribution of Working Group II to the Fifth Assessment Report of the Intergovernmental Panel on Climate Change, , Cambridge University Press, Cambridge and New York.

Linnerooth-Bayer, J., Mace, M.J. and Verheyen, R. (2003) Insurance-Related Actions and Risk Assessment in the Context of the UNFCCC, background paper for UNFCCC workshops commissioned by UNFCCC secretariat [online] http://unfccc.int/files/meetings/workshops/other_meetings/application/pdf/background.pdf (accessed 5 October 2013).

Mace, M.J. (2005) 'Funding for adaptation to climate change: UNFCCC and GEF developments since COP-7', Review of European Community and International Environmental Law, Vol. 14, No. 3, pp.225-246.

Malakoff, D. (1997) 'Thirty Kyotos needed to control warming', Science, Vol. 278, No. 5346, p.2048.

Najam, A. and Sagar, A. (1998) 'Avoiding a COP-out: moving towards systematic decision-making under the climate convention', Climate Change, Vol. 39, No. 4, pp.iii-ix.

Nordhaus, W.D. (1994) Managing the Global Commons: the Economics of Climate Change, Massachusetts Institute of Technology, Cambridge, MA.

Parry, M.L., Canziani, O.F., Palutikof, J.P., van der Linden, P.J. and Hanson, C.E. (Eds.) (2007) Contribution of Working Group II to the Fourth Assessment Report of the Intergovernmental Panel on Climate Change, Cambridge University Press, Cambridge.

Pielke Jr., R., Prins, G., Rayner, S. and Sorewitz, D. (2007) 'Lifting the taboo on adaptation', Nature, Vol. 445, pp.597-598.

Pielke Jr., R.A. (1998) 'Rethinking the role of adaptation policy', Global Climate Change, Vol. 8, No. 2, pp.59-170. 
'Politicians sweat over global warming' (1997) Science, Vol. 278, No. 5346, p.2040.

Preston, B.L., Dow, K and Berkhout, F. (2013) 'The climate adaptation frontier', Sustainability, Vol. 5, No. 3, pp.1011-1035.

Ramakrishna, K. (2000) 'The UNFCCC - history and evaluation of the climate change negotiations', in Gómez-Echeverri, L. (Ed.): Climate Change and Development, Yale School of Forestry and Environmental Studies, New Haven.

Sands, P. (1992) 'United Nations framework convention on climate change', Review of European Community and International Law, Vol. 1, No. 3, pp.270-277.

Schimel, D., Alves, D., Enting, I., Heimann, M., Joos, F., Raynaud, D., Wigley, T., Prather, M., Dervent, R., Ehhalt, D., Fraser, P., Sanheuza, E., Zhou, Z., Jonas, P., Charlson,R., Rodhie, H., Sadasivan, S., Solomon, S., Srivivasan, J., Albritton, D., Isaksen, I., Lal, M. and Wuebbles, D. (1996) 'Radioactive forcing of climate change', in Houghton, J.T., Meira Filho, L.G., Callander, B.A., Harris, N., Kattenberg, A. and Maskell, K. (Eds.): Climate Change 1995 The Science of Climate Change: Contribution of Working Group I to the Second Assessment Report of the Intergovernmental Panel on Climate Change, Cambridge University Press, Cambridge, New York and Melbourne.

Schipper, E.L.F. (2006) 'Conceptual history of adaptation in the UNFCCC process', Review of European Community and International Environmental Law, Vol. 15, No. 1, pp.82-92.

Schneider, S.H. (1998) 'Kyoto Protocol: the unfinished agenda,' Editorial essay, Climate Change, Vol. 39, No. 1, pp.1-21.

Sherwood, S. (2011) 'Science controversies past and present', Physics Today, Vol. 64, No. 10, pp.39-44.

Smit, B., Pilifosova, O., Burton, I., Challeger, B., Huq, S., Klein, R.J.T. and Yohne, G. (2001) 'Adaptation to climate change in the context of sustainable development', in McCarthy, J.J., Canziani, O.F., Leary, N.A., Dokken, D.J. and White, K.S. (Eds.): Climate Change 2001: Impacts, Adaptation, and Vulnerability, Cambridge University Press, Cambridge and New York [online] http://www.grida.no/publications/other/ipcc_tar/?src=/climate/ipcc_tar/ (accessed 23 November 2013).

Smithers, J. and Smit, B. (1997) 'Human adaptation to climatic variability and change', Global Environmental Change, Vol. 7, No. 2, pp.129-146.

Tarlock, D. (1992) 'Now, think again about adaptation', Arizona Journal of International and Comparative Law, Vol. 9, No. 2, pp.169-182.

Tol, R.S.J. (2005) 'Adaptation and mitigation: trade-offs in substance and methods', Environmental Science and Policy, Vol. 25, No. 6, pp.572-578.

UN (1992) United Nations Framework Convention on Climate Change, FCCC/INFORMAL/84.

UN General Assembly (1988) United Nations General Assembly Resolution 43/53: Protection of Global Climate for Present and Future Generations of Mankind, A/RES/43/53.

UN General Assembly (1990) United Nations General Assembly Resolution 45/212: Protection of Global Climate for Present and Future Generations of Mankind, A/RES/45/212.

UNFCCC (1995) Report of the Conference of the Parties on its First Session, Berlin, 28 March-7 April 1995, Addendum, FCCC/CP/1995/7/Add.1.

UNFCCC (1998) Kyoto Protocol to the UNFCCC [online] $\mathrm{http} / / / \mathrm{unfccc}$.int/resource/docs/convkp/kpeng.pdf (accessed 17 January 2013).

UNFCCC (2002) Report of the Conference of the Parties on its Seventh Session, Marrakesh, 29 October-10 November 2001, Addendum, FCCC/CP/2001/13/Add.1.

UNFCCC (2003) Report of Conference of the Parties, on its Eighth Session, Delhi, 23 October-1 November 2003, Addendum, FCCC/CP/2002/7/Add.1.

UNFCCC (2004) Report of Conference of the Parties on Its Ninth Session, Milan, 1-12 December 2003, Addendum, FCCC/CP/2003/6/Add.1.

UNFCCC (2006) Report of Conference of the Parties on its Eleventh Session, Montreal, 28 November -10 December 2005, Addendum, FCCC/CP/2005/5/Add.1. 
UNFCCC (2007) Report of Conference of the Parties, on its Twelfth Session, Nairobi, 6-17 November 2007, Addendum, FCCC/CP/2006/5/Add.1.

UNFCCC (2008) Report of Conference of the Parties, on its Thirteenth Session, Bali, 3-15 December 2007, Addendum, FCCC/CP/2007/6/Add.1.

UNFCCC (2011a) Report of Conference of the Parties, on its Sixteenth Session, Cancun, 29 November-10 December 2010, Addendum, FCCC/CP/2009/11/Add.1.

UNFCCC (2011b) Report of the Subsidiary Body for Implementation on its Thirty-Fourth Session, Bonn, 6-17 June 2011, FCCC/SBI/2011/7.

UNFCCC (2012a) A Literature Review on the Topics in the Context of Thematic Area 2 of the Work Programme on Loss and Damage: A Range of Approaches to Address Loss and Damage Associated with the Adverse Effects of Climate Change, FCCC/SBI/2012/INF.14.

UNFCCC (2012b) Three-year Workplan of the Adaptation Committee, $\mathrm{http}: / /$ unfccc.int/files/adaptation/cancun_adaptation_framework/adaptation_committee/applica tion/pdf/work_plan_final.pdf (accessed 17 January 2013 ).

UNFCCC (2012c) Report of Conference of the Parties, on its Seventeenth Session, Durban, 28 November to 11 December 2011, Addendum, FCCC/CP/2010/7/Add.1.

UNFCCC (2013) Report of the Conference of the Parties on Its Eighteenth Session, Doha, 26 November to 8 December 2012, FCCC/CP/2008/8/Add.1.

UNFCCC (2014) Report of the Conference of the Parties on its Nineteenth Session, Warsaw, 11-23 November 2013, Addendum, FCCC/CP/2013/10/Add.1.

UNFCCC (n.d.) Status of Ratification of the Convention [online] http://unfccc.int/essential_background/convention/status_of_ratification/items/2631.php (accessed 19 January 2013).

Verheyen, R. (2012) Tackling Loss \& Damage - A New Role for the Climate Regime?, Germanwatch, Bonn.

Vidal, G. and Vaughan, A. (2013) Philippines Urges to Resolve Climate Talks Deadlock after Typhoon Haiyan, The Guardian [online]

http://www.theguardian.com/environment/2013/nov/11/typhoon-haiyan-philippines-climatetalks (accessed 29 January 2014).

Warner, K. and van der Geest, K. (2013) 'Loss and damage from climate change: Local-level evidence from nine vulnerable countries', International Journal of Global Warming, Vol. 5, No. 4, pp.367-386.

Warner, K. and Zakieldeen, S.A. (2012) Loss and Damage Due to Climate Change: An Overview of the UNFCCC Negotiations, European Capacity Building Initiative, Oxford.

Weart, S. (2010) 'The idea of anthropogenic global climate change in the 20th century', WIREs Climate Change, Vol. 1, pp.67-81 [online] cigionline.org/geoeng/2010\%20-\%20Weart\%20\%20The\%20Idea\%20of\%20Anthropogenic\%20Global\%20Climate\%20Change.pdf (accessed 23 January 2014).

WMO (1988) 'The changing atmosphere: implications for global security', Conferencing Proceedings, WMO No. 710, Toronto, Canada, 27-30 June 1988 [online] http://www.cmos.ca/ChangingAtmosphere1988e.pdf (accessed 26 November 2013). 